\title{
Arsène Houssaye, De Profundis
}

\section{Lise Sabourin}

\section{(2) OpenEdition}

\section{Journals}

\section{Édition électronique}

URL : http://journals.openedition.org/studifrancesi/33468

DOI : 10.4000/studifrancesi.33468

ISSN : 2427-5856

\section{Éditeur}

Rosenberg \& Sellier

\section{Édition imprimée}

Date de publication : 1 décembre 2005

Pagination : 666

ISSN : 0039-2944

\section{Référence électronique}

Lise Sabourin, «Arsène Houssaye, De Profundis », Studi Francesi [En ligne], 147 (XLX | III) | 2005, mis en ligne le 30 novembre 2015, consulté le 20 avril 2021. URL : http://journals.openedition.org/ studifrancesi/33468; DOI : https://doi.org/10.4000/studifrancesi.33468

\section{Ce document a été généré automatiquement le 20 avril 2021.}

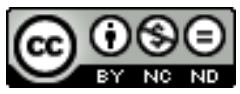

Studi Francesi è distribuita con Licenza Creative Commons Attribuzione - Non commerciale - Non opere derivate 4.0 Internazionale. 


\title{
Arsène Houssaye, De Profundis
}

\author{
Lise Sabourin
}

\section{RÉFÉRENCE}

ARSÈNE HOUSSAYE, De Profundis, édition d'EMMANUELLE OBRINGER, Jaignes (Seine et Marne), La Chasse au Snark, 2001, pp. 240.

1 Né dans l'effervescence artistique de 1834, ce petit roman d'Houssaye se situe dans la lignée des écrits de Janin, Borel, Lassailly et Rabbe. Imitatif des modèles de la Monarchie de Juillet, il cultive le non-conformisme au point de s'en révéler parodique à l'aube de la littérature industrielle dont il caricature les tendances à la facilité. Abusant des clichés, allusions et références épigraphiques, il ironise des outrances mêmes du romantisme dont il participe: étirement de l'exposition, banalité des personnagestypes, mise en abyme d'effets frénétiques s'affichent au sein d'une conduite volontairement décousue des chapitres. Le dialogue entre aspirants écrivains dans les lieux-ateliers du roman (cabinet de lecture, bibliothèque) les confronte aux succès des gloires déjà assises (Hugo, Lewis, Musset) et aboutit à une ambiguïté qui charme le lecteur par le sérieux profond de cette fantaisie juvénile qui constitue en réalité une réflexion sur l'art romanesque. 